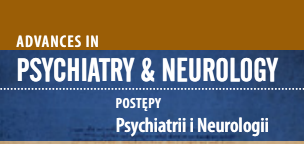

Correspondence to/Adres do korespondencji:

Tomasz Stępień

Department of Neuropathology

Institute of Psychiatry and Neurology

9 Sobieskiego St.

02-957 Warsaw, Poland

e-mail: tstepien@ipin.edu.pl

Submitted/Otrzymano: 06.10.2021

Accepted/Przyjęto do druku: 28.11.2021

\section{Neurogenesis in neurodegenerative diseases in the adult human brain}

\section{Neurogeneza w chorobach neurodegeneracyjnych u osób dorosłych}

\author{
Tomasz Stępień (D) \\ Department of Neuropathology, Institute of Psychiatry and Neurology, Warsaw, \\ Poland
}

\begin{abstract}
Purpose: Adult human brain neurogenesis is the process of cell division, differentiation, and integration of the new neurons in the brain. The neurons that arise in subventricular zone migrate to the olfactory bulb, while the newly formed neurons in the dentate gyrus migrate locally. In adult neurogenesis starting from neural stem cells, in addition to glial neurons astrocytes and oligodendrocytes are also formed. Neurogenesis is regulated by endogenous and exogenous factors influencing the proliferation potential of progenitor cells and accelerating the rate of development of the dendritic connections of newly formed neurons.

Views: The slow, initial process of a developing neurodegenerative disease may have a stimulating effect on neurogenesis. Increased levels of pro-inflammatory factors may contribute to the formation of new neurons. A similar hypothesis seems to be confirmed by data in the literature. The importance of proneurogenic effects during inflammation is shown by proteins secreted by active microglia, mainly CD 47 and CD 55 and interleukin 4 and 10. On the other hand, the unfavorable effect of the inflammatory process in the brain is usually associated with chronic disease in it, when stimulated microglia increase the concentration of cytokines that have a negative effect on neurogenesis.

Conclusions: Restoring the balance between dying and emerging neurons is important and offers hope for new therapy directions in the treatment of neurodegenerative diseases. We note common points that could become the target of further research. Attention should be paid to disorders of the calcium metabolism, so important in signal transduction, the state of mitochondria with enzymes involved in the formation of ATP, and the reduction of inflammation in neurogenic regions.
\end{abstract}

Key words: neurogenesis, adult human brain, neurodegenerative disease.

\title{
Streszczenie
}

Cel: Neurogeneza mózgu dorosłego człowieka to proces podziału komórek, różnicowania i integracji nowych neuronów w mózgu. Neurony powstające w strefie podkomorowej migrują do opuszki węchowej, podczas gdy nowo powstałe neurony w zakręcie zębatym migrują lokalnie. W neurogenezie dorosłych, począwszy od neural stem cells, oprócz neuronów glejowych powstają także astrocyty i oligodendrocyty. Neurogeneza jest regulowana przez czynniki endogenne i egzogenne wpływające na potencjał proliferacyjny komórek progenitorowych i zwiększające tempo rozwoju połączeń dendrytycznych nowo powstałych neuronów.

Poglądy: Początkowy powolny proces rozwijającej się choroby neurodegeneracyjnej może wpływać stymulująco na neurogenezę. Podwyższony poziom czynników prozapalnych może przyczynić się do powstania nowych neuronów. Podobną hipotezę wydają się potwierdzać dane literaturowe. O znaczeniu proneurogennym w przebiegu stanu zapalnego świadczą białka wydzielane przez aktywny mikroglej. Z drugiej strony niekorzystny wpływ procesu zapalnego w mózgu jest zwykle związany z jego przewlekłą chorobą, gdyż stymulowany mikroglej zwiększa stężenie cytokin, które mają negatywny wpływ na neurogenezę.

Wnioski: Przywrócenie równowagi między umierającymi a powstającymi neuronami jest ważne i daje nadzieję na nowe kierunki terapii w leczeniu chorób neurodegeneracyjnych. Dostrzegamy punkty wspólne, które mogą stać się celem dalszych badań. Na uwagę zasługują zaburzenia gospodarki wapniowej, tak ważne w transdukcji sygnału, stan mitochondriów z enzymami biorącymi udział w tworzeniu ATP, a także zmniejszenie stanu zapalnego w obszarach neurogennych.

Słowa kluczowe: neurogeneza, mózg dorosłego człowieka, choroba neurodegeneracyjna. 


\section{INTRODUCTION}

Millions of people around the world suffer from neurodegenerative diseases and scientists are still looking for new treatment methods. Our understanding of the fine balance between neurogenesis - the creation of new neurons and their elimination - has made it possible to revisit the neurodegenerative process in the context of the creation of new neurons. Neurogenesis is the process of cell division, differentiation, and integration of the new neurons in the brain. Until the 1960s, it was believed that the central nervous system had no regenerative capacity, and that the creation of new neurons in the brain was restricted to the fetal period. Thanks to new radiolabeling methods for thymidine $\left({ }^{3} \mathrm{H}\right.$-thymidine), Joseph Altman and Goal Das observed the appearance of new neurons in an animal model [1]. 20 years later, the development of a research technique using the BrdU method happened to discover newly formed neurons in the brains of adult canaries [2]. There was no confirmation of this process in the adult human brain. In 1998 Erikson published the results of research in which transcriptionally active cells in the dentate gyrus (DG) and the subventricular zone (SVZ) were shown, using BrdU labelling [3].

In 2018 Sorrells published the manuscript questioning the formation of new neurons in adult human brain in subventricular zone (SVZ) and dentate gyrus (DG) in hippocampus [4]. Sorrells' in his study shows that neurogenesis declines with age. It reaches its highest level in the prenatal and perinatal period, slowly calming down until it almost completely disappears in adult human brain. Perhaps this is due to the methods used or the method of fixation the material. The publication caused quite a stir in the scientific community and aroused a lot of emotions. It also stands in opposition to numerous publications which confirm the formation of new neurons in SVZ and DG in animal models also in neurodegenerative diseases in human [5]. There are still many unresolved questions about neurogenesis. The authors of this review observed newly born neurons in adult human brain, also in old age, and their experimental research confirms the existence of neurogenesis and beyond any doubt [6].

Adult human brain neurogenesis is not a simple continuation of fetal period neurogenesis. The neurons that arise in the SVZ migrate to the olfactory bulb, while the newly formed neurons in the dentate gyrus migrate locally [7]. Some studies show the aggregation of neuronal stem cells (NSCs) in other meningeal stem structures also: in the frontal and temporal cortex, in the amygdala, hypothalamus, and in the subcortical layer of white matter [8]. In adult neurogenesis, starting from NSCs, apart from glial neurons astrocytes and oligodendrocytes are also formed. New neurons that arise from the NSC go through successive stages of development.
Initially, they begin neuronal progenitor cell (NPCs) neuroblasts, then the production of' premature neurons and neurons [9]. Three types of proliferatively active cells have been identified in the granular layer of the dentate gyrus (DG) of the hippocampus: type I cells - radial glial-like stem cells expressing glial fibrillary acidic protein (GFAP) and Sox2; type II cells - non-sessile cells expressing nestin, also referred to as transiently activated progenitor cells, neuroblasts expressing doublecortin (DCX); and Ki67 proteins and immature neurons expressing the DCX protein, PSA-NCAM, a marker of migrating neurons (polysialylated neuronal cell adhesion molecules) and neuron-specific protein (NeuN) $[10,11]$. On the other hand, three types of cells were distinguished in the subventricular zone (SVZ): B1-type astrocytic stem cells, GFAP-positive, C-type progenitor cells expressing the Mash1 protein, and neuroblasts expressing the DCX protein [12].

\section{NEUROGENESIS FACTORS}

Adult human brain neurogenesis is regulated by endogenous and exogenous factors influencing the proliferation potential of progenitor cells and accelerating the rate of development of the dendritic connections of newly formed neurons. The factors influencing the dynamics of neurogenesis and the total number of neurons include stress, diet, physical activity, alcohol, drugs, and medications [13]. Physical activity and caloric restriction also have neurogenic effects, mediated by the brainderived neurotrophic factor (BDNF) [14]. Movement lowers cortisol levels and oxygenates the body. It increases the number of cells formed in the dentate gyrus and their survival time. Research also shows that reducing the number of calories consumed by $30-40 \%$ stimulates neurogenesis [15]. It has even been suggested that small doses of some psychoactive substances have a stimulating effect on the activity of newly formed neurons and the dynamics of neurogenesis $[16,17]$. The mechanism of action of D-amphetamine on the formation and differentiation of new nerve cells involves the activation pathway of neurotrophins through the p75 and Trk receptors. The reaction of neutrophins with the 75 receptor directs cells to apoptosis, while the binding of neutrophins to Trk receptors stimulates the survival and differentiation of neurons [18]. BDNF binds to several receptors, such as p75 and Trk receptors. It is unclear how BDNF stimulates TrkB expression in precursor cells [19]. The main modifiers of neurogenesis are growth factors and neurotransmitters, mainly serotonin, noradrenaline, dopamine, acetylcholine and GABA acid and glutamate, as well as environmental factors. GABA is an inhibitory neurotransmitter, released mainly by interneurons and astrocytes. It takes part in the depolarization of the membrane of progenitor cells and immature neurons during neurogenesis [20]. 
Glutamate and serotonin stimulate the proliferation of NSCs in the DG and SVZ region [21]. Glutamate stimulates neurogenesis and increases the synthesis of trophic factors such as BDNF and FGF - by activating glutamatergic receptors [22]. In a similar mechanism, serotonin stimulates neurogenesis. By activating $5 \mathrm{HT}$ receptors, it influences the synthesis of growth factors [21]. The most important growth factors include epithelial growth factor (EGF), stimulating cell division and the differentiation of stem cells into neurons and astrocytes, the fibroblast growth factor (FGF) determining the differentiation of new cells [23], and the brain neurotrophic factor (BDNF), increasing the survival of newly formed cells [24]. Infusions of BDNF into the hippocampus have been shown to enhance neurogenesis [25]. There is ample evidence of a key role of the BDNF in the regulation of neurogenesis in the dentate gyrus of the adult brain [19]. The BDNF is also responsible for the regulation of mood, which directly correlates with the neurogenic effects of antidepressants. Administration of the BDNF to the dentate gyrus mimics the effects of antidepressants, as confirmed by behavioral tests, and increases the level of neurogenesis in the subventricular zone [15].

\section{HYPOTHESIS}

The slow, initial process of a developing neurodegenerative disease may have a stimulating effect on neurogenesis. Increased levels of pro-inflammatory factors may contribute to the formation of new neurons. A similar hypothesis seems to be confirmed by data in the literature. The importance of proneurogenic effects during inflammation is shown by proteins secreted by active microglia, mainly CD 47 and CD 55 and interleukin 4 and 10 [26]. On the other hand, the unfavorable effect of the inflammatory process in the brain is usually associated with chronic disease in it, when stimulated microglia increase the concentration of cytokines that have a negative effect on neurogenesis, e.g. IL-6, IL-1 $\beta$, IL-1 $\alpha$ and TNF [27].

\section{NEUROGENESIS IN ALZHEIMER'S DISEASE}

Alzheimer's disease (AD) is one of the most common neurodegenerative diseases. Its etiopathogenesis is not fully understood yet. It is known to be associated with the impairment of some metabolic pathways, and the incidence increases with age. There is also a correlation between the progression of Alzheimer's disease and loss of neuronal function [28]. One of the many causes of Alzheimer's disease is the impaired degradation of misfolded proteins. Disorders of this process lead to $\beta$-amyloid aggregation and the formation of toxic deposits, which are also markers of the disease [29].
The neurotoxicity of pathological forms of $\beta$-amyloid is related, inter alia, to from disturbances in the $\mathrm{Ca}^{2+}$ ion metabolism, interaction with cell membrane lipids, and activation of specific receptors. It then causes significant damage to the glutamatergic neurons in the hippocampus and cortex of the brain [30]. Malfunctioning neurons are believed to release too much glutamic acid, the metabolites of which are toxic and lead to cell death. Under physiological conditions, glutamate stimulates the regulation of neurogenesis by activating cells located in the vicinity of the brain's progenitor cells [22]. Studies on animalmodels show thatblockingglutamatergic signaling reduces cell proliferation significantly $[11,31]$. In addition to the glutamatergic system in neurogenesis and pathogenesis in Alzheimer's disease, the cholinergic system plays an important role. The research clearly confirms the important role of acetylcholine in the formation of new neurons in the dentate gyrus of the hippocampus [32]. Understanding the mechanism of blocking the enzyme responsible for the hydrolysis of acetylcholine at the synapse has resulted in new therapy in Alzheimer's disease [33]. It has been noticed that proteins involved in the process of the development of neurodegenerative diseases participate, under physiological conditions, in the regulation of brain plasticity during its development [34]. While searching for new therapeutic methods, it was discovered that the slow neurodegenerative process can induce neurogenesis [35]. The mechanism of this process has not yet been understood, and the research has so far been focused on animal models and cell cultures [36].

\section{NEUROGENESIS IN PARKINSON'S DISEASE}

Parkinson's disease (PD) is the second most common neurodegenerative disease. It is estimated that about $1 \%$ of the population over the age of 60 suffers from this disease [37]. It is a process of slow, progressive loss of dopaminergic neurons. PD is a multifactorial disease, with both genetic and environmental factors playing a role. Hereditary type of PD may be caused by a specific mutation in one of the genes: $\alpha$-synuclein, parkin, ubiquitin L1 hydrolase, PINK1 kinase and others. The core symptoms of Parkinson's disease are akinesia, rigidity and tremor. Over time, movement disorders are accompanied by further non-motor symptoms, such as autonomic, cognitive and emotional disorders [38]. Progressive inflammation, along with oxidative stress and dysfunction of the respiratory chain in the mitochondria, contributes to the loss of mitochondria [39]. The neuropathological picture shows the degeneration of dopaminergic neurons in the substantia nigra. Dopamine levels drop in patients, but changes in the norepinephrine, adrenaline, serotonin, acetylcholine, and 
GABA pathways are also found. The decrease in dopamine levels leads to a decrease in NSC proliferation and neurogenesis activity in the SVZ region $[8,11]$. Interestingly, cell culture studies do not indicate a significant effect of dopamine on the stimulation of NSC proliferation [40]. In contrast, many scientists report the positive, neuroprotective effect of L-Dopa used in the treatment of PD on the increase in NSC proliferation [41]. Studies on an animal model indicate a special role of mitochondria in the disease process. $\alpha$-synuclein deposits observed in Parkinson's disease locate in the mitochondria, causing their fragmentation and mitochondrial dysfunction. $\alpha$-synuclein-deficient mice indicate an increased level of neurogenesis [42]. In contrast, the overexpression of $\alpha$-synuclein in rats reduces the proliferation and survival of NSCs and impairs the process of dendrite formation by neuroblasts [43]. The protein kinase PINK1 is involved in the control of mitochondria. Patients with the PINK1 or parkin mutation show an accumulation of a-synuclein with accompanying abnormal mitochondrial morphology, increased susceptibility to toxins and oxidative stress [44]. In recent years, scientists have been seeing therapeutic targets in stimulating neurogenesis, which may contribute to the formation of dopaminergic neurons in the substantia nigra [45]. Stimulating the proliferation of progenitor cells in the SVZ region leads to an increase in the number of dopaminergic neurons in the substantia nigra in a mouse model of Parkinson's disease. These results suggest that mitochondria should be a potential therapeutic target in the stimulation of neurogenesis, but this requires further research [46].

\section{NEUROGENESIS IN HUNTINGTON'S DISEASE}

Huntington's disease (HD) is an inherited autosomal dominant neurodegenerative disease. Apart from cognitive symptoms, the main symptom of the disease is chorea - initially focal, with a tendency to generalize in the later stages of the disease. Gait disturbances are characteristic, with significant instability and the risk of falls. It is estimated that falls occur in $60 \%$ of patients and correlate with the severity of both movement disorders and neuropsychiatric disorders [47]. Contrary to the above-mentioned disease entities, its etiology is relatively well understood and is associated with an increased occurrence of CAG nucleotides (cytosine, adenine, guanine). There is an overabundance of CAG triplets in the huntingtin (HTT) gene, which are converted to polyglutamine (poly Q) residues at the end of the huntingtin (HTT) protein, changing the protein's properties. Under physiological conditions, the number of CAG repeats in the HTT gene is 6-35. On the other hand, if the number of CAG repeats exceeds 40 , the huntingtin begins to form toxic protein aggregates in the nuclei of neurons, causing them to die.
The greatest changes occur in the medium spiny neurons (MSN) of the striatum, which are responsible for motor functions [48]. The time of disease onset largely depends on the number of CAG triplets, and the more this changes, the more advanced the disease phenotype. We also observe the phenomenon of gene anticipation, i.e., the intensification of previously occurring disease symptoms in subsequent generations. The effects of Huntington's disease on neurogenesis have been studied in animal models. Studies in HD transgenic mice have shown a marked decrease in the level of neurogenesis within the DG in adult mice of the R6/1 line or R6/2 [49]. It showed a marked decrease in proliferation and differentiation, resulting in a reduction in the total number of neurons in the hippocampus. Interestingly, no differences in neural formation within the SVZ were observed [49]. On the other hand, immunohistochemical studies on human material based on the labelling of PCNA cells showed an increase in neurogenesis in the sub-lining layer of the lateral ventricles. The observed differences may be due to more huntingtin deposits being present in the human striatum than in mice. Increased degeneration of striatal neurons may contribute to increased neurogenesis in the adjacent sub-lining layer of the lateral ventricles. This is supported by animal models of quinolinic acid-induced Huntington's disease, where striatal damage has stimulated neurogenesis within the SVZ [50]. Research explaining the mechanism of the disease mainly shows the presence of huntingtin. The correct form of huntingtin promotes BDNF expression by interacting with the REST/ NRSF transcription factor in the cytoplasm and preventing the complex from translocating into the nucleus. In contrast, the mutant form of huntingtin does not interact with REST/NRSF in the cytoplasm, leading to its accumulation in the nucleus and a reduction in BDNF levels [51]. Animal models also indicate a decreased level of dopamine in the striatum as a factor that reduces neurogenesis [52]. Interesting conclusions arise from studies on cell cultures, where the genes responsible for the calcium metabolism were studied. Increasing the activity of the IP3R receptor through overexpression of the Huntingtin Associated Protein 1 (HAP1) protein causes disruption of $\mathrm{Ca}^{2+}$ ion transport and, consequently, the death of neurons [53].

\section{CONCLUSIONS}

Restoring the balance between dying and emerging neurons is important and offers hope for new therapy directions in the treatment of neurodegenerative diseases. We have noted common points that could become the target of further research. Attention should be paid to disorders of the calcium metabolism, so important in signal transduction, the state of mitochondria with enzymes involved in the formation of ATP, and the reduction of inflammation in neurogenic regions. 
Neurogenesis in neurodegenerative diseases in the adult human brain

Neurogeneza w chorobach neurodegeneracyjnych u osób dorosłych

\section{Conflict of interest/Konflikt interesu}

Absent./Nie występuje.

\section{Financial support/Finansowanie}

The publication was supported by the Institute of Psychiatry and Neurology statutory fund No. 501-42-071-19021./Praca finansowana z grantu nr 501-42-071-19021 Instytutu Psychiatrii i Neurologii.

\section{References/Piśmiennictwo}

1. Altman J, Das GD. Autoradiographic and histological evidence of postnatal hippocampal neurogenesis in rats. J Comp Neurol 1965; 124: 319-335.

2. Goldman SA. Adult neurogenesis: from canaries to the clinic. J Neurobiol 1998; 36: 267-286.

3. Eriksson PS, Perfilieva E, Björk-Eriksson T, Alborn AM, Nordborg C, Peterson DA, Gage FH. Neurogenesis in the adult human hippocampus. Nat Med 1998; 4: 1313-1317.

4. Sorrells SF, Paredes MF, Cebrian-Silla A, Sandoval K, Qi D, Kelley KW, et al. Human hippocampal neurogenesis drops sharply in children to undetectable levels in adults. Nature 2018; 555: 377-381.

5. Barreto Nogueira A, Sayuri Ramires Hoshino H, Camargo Ortega N, Silva Dos Santos BG, Jacobsen Teixeira M. Adult human neurogenesis: early studies clarify recent controversies and go further. Metab Brain Dis 2021. DOI: 10.1007/s11011-021-00864-8.

6. Stępień T, Tarka S, Chutorański D, Felczak P, Acewicz A, Wierzba-Bobrowicz T. Neurogenesis in adult human brain after hemorrhage and ischemic stroke. Folia Neuropathol 2018; 56: 293-300.

7. Gascon E, Vutskits L, Kiss JZ. The role of PSA-NCAM in adult neurogenesis. Adv Exp Med Biol 2010; 663: 127-136.

8. Ming GL, Song H. Adult neurogenesis in the mammalian brain: significant answers and significant questions. Neuron 2011; 70: 687-702.

9. Denoth-Lippuner A, Jessberger S. Formation and integration of new neurons in the adult hippocampus. Nat Rev Neurosci 2021; 22: 223-236.

10. Attardo A, Fabel K, Krebs J, Haubensak W, Huttner WB, Kempermann G. Tis21 expression marks not only populations of neurogenic precursor cells but also new postmitotic neurons in adult hippocampal neurogenesis. Cereb Cortex 2010; 20: 304-314.

11. Gault N, Szele FG. Immunohistochemical evidence for adult human neurogenesis in health and disease. WIREs Mech Dis 2021; 13: e1526.

12. Okano H, Sawamoto K. Neural stem cells: involvement in adult neurogenesis and CNS repair. Philos Trans R Soc Lond B Biol Sci 2008; 363: 2111-2122.

13. Santarelli L, Saxe M, Gross C, Surget A, Battaglia F, Dulawa S, et al. Requirement of hippocampal neurogenesis for the behavioral effects of antidepressants. Science 2003; 301: 805-809.

14. Schoenfeld TJ, Swanson C. A runner's high for new neurons? Potential role for endorphins in exercise effects on adult neurogenesis. Biomolecules 2021; 11: 1077.

15. Zhao C, Deng W, Gage FH. Mechanisms and functional implications of adult neurogenesis. Cell 2008; 132: 645-660.

16. Rotllant D, Márquez C, Nadal R, Armario A. The brain pattern of c-fos induction by two doses of amphetamine suggests different brain processing pathways and minor contribution of behavioural traits. Neuroscience 2010; 168: 691-705.

17. Stępień T, Taracha E, Kaniuga E, Płaźnik A, Wierzba-Bobrowicz T. Effects of amphetamine administration on neurogenesis in adult rats. Folia Neuropathol 2017; 55: 333-339.

18. Ceni C, Kommaddi RP, Thomas R, Vereker E, Liu X, McPherson PS, et al. The p75NTR intracellular domain generated by neurotrophin-induced receptor cleavage potentiates Trk signaling. J Cell Sci 2010; 123 (Pt 13): 2299-2307.

19. Russo-Neustadt AA, Alejandre H, Garcia C, Ivy AS, Chen MJ. Hippocampal brain-derived neurotrophic factor expression following treatment with reboxetine, citalopram, and physical exercise. Neuropsychopharmacology 2004; 29: 2189-2199.

20. Berg DA, Belnoue L, Song H, Simon A. Neurotransmitter-mediated control of neurogenesis in the adult vertebrate brain. Development 2013; 140: 2548-2561.

21. Banasr M, Hery M, Printemps R, Daszuta A. Serotonin-induced increases in adult cell proliferation and neurogenesis are mediated through different and common 5-HT receptor subtypes in the dentate gyrus and the subventricular zone. Neuropsychopharmacology 2004; 29: 450-460.

22. Schlett K. Glutamate as a modulator of embryonic and adult neurogenesis. Curr Top Med Chem 2006; 6: 949-960.

23. Kuhn HG, Winkler J, Kempermann G, Thal LJ, Gage FH. Epidermal growth factor and fibroblast growth factor-2 have different effects on neural progenitors in the adult rat brain. J Neurosci 1997; 17: 5820-5829.

24. Jin K, Zhu Y, Sun Y, Mao XO, Xie L, Greenberg DA. Vascular endothelial growth factor (VEGF) stimulates neurogenesis in vitro and in vivo. Proc Natl Acad Sci U S A 2002; 99: 11946-11950.

25. Scharfman HE. Brain-derived neurotrophic factor and epilepsy - a missing link? Epilepsy Curr 2005; 5: 83-88. 
26. Fuster-Matanzo A, Llorens-Martín M, Hernández F, Avila J. Role of neuroinflammation in adult neurogenesis and Alzheimer disease: therapeutic approaches. Mediators Inflamm 2013; 2013: 260925.

27. Lucassen PJ, Meerlo P, Naylor AS, van Dam AM, Dayer AG, Fuchs E, et al. Regulation of adult neurogenesis by stress, sleep disruption, exercise and inflammation: Implications for depression and antidepressant action. Eur Neuropsychopharmacol 2010; 20: 1-17.

28. Hardy J, Selkoe DJ. The amyloid hypothesis of Alzheimer's disease: progress and problems on the road to therapeutics. Science 2002; 297: 353-356.

29. Carter J, Lippa CF. Beta-amyloid, neuronal death and Alzheimer's disease. Curr Mol Med 2001; $1: 733-737$.

30. Young JK. Neurogenesis makes a crucial contribution to the neuropathology of Alzheimer's disease. J Alzheimers Dis Rep 2020; 4: 365-371.

31. Uchida N, Kiuchi Y, Miyamoto K, Uchida J, Tobe T, Tomita M, et al. Glutamate-stimulated proliferation of rat retinal pigment epithelial cells. Eur J Pharmacol 1998; 343: 265-273.

32. Veena J, Rao BS, Srikumar BN. Regulation of adult neurogenesis in the hippocampus by stress, acetylcholine and dopamine. J Nat Sci Biol Med 2011; 2: 26-37.

33. Cummings JL. Drug therapy: Alzheimer's disease. N Engl J Med 2004; 351: 56-67.

34. Abeliovich A, Schmitz Y, Fariñas I, Choi-Lundberg D, Ho WH, Castillo PE, et al. Mice lacking a-synuclein display functional deficits in the nigrostriatal dopamine system. Neuron 2000; 25: 239-252.

35. Moreno-Jiménez EP, Flor-García M, Terreros-Roncal J, Rábano A, Cafini F, Pallas-Bazarra N, et al. Adult hippocampal neurogenesis is abundant in neurologically healthy subjects and drops sharply in patients with Alzheimer's disease. Nat Med 2019; 25: 554-560.

36. Lopez-Toledano MA, Shelanski ML. Neurogenic effect of b-amyloid peptide in the development of neural stem cells. J Neurosci 2004; 24: 5439-5444.

37. Blauwendraat C, Heilbron K, Vallerga CL, Bandres-Ciga S, von Coelln R, Pihlstrøm L, et al. Parkinson's disease age at onset genome-wide association study: defining heritability, genetic loci, and a-synuclein mechanisms. Mov Disord 2019; 34: 866-875.

38. Nguyen M, Wong YC, Ysselstein D, Severino A, Krainc D. Synaptic, mitochondrial, and lysosomal dysfunction in Parkinson's disease. Trends Neurosci 2019; 42: 140-149.

39. van den Berge SA, van Strien ME, Korecka JA, Dijkstra AA, Sluijs JA, Kooijman L, et al. The proliferative capacity of the subventricular zone is maintained in the parkinsonian brain. Brain 2011; 134 (Pt 11): 3249-3263.

40. O'Sullivan SS, Johnson M, Williams DR, Revesz T, Holton JL, Lees AJ, et al. The effect of drug treatment on neurogenesis in Parkinson's disease. Mov Disord 2011; 26: 45-50.

41. Winner B, Regensburger M, Schreglmann S, Boyer L, Prots I, Rockenstein E, et al. Role of $\alpha$-synuclein in adult neurogenesis and neuronal maturation in the dentate gyrus. J Neurosci 2012; 32: 16906-16916.

42. Kohl Z, Abdallah NB, Vogelgsang J, Tischer L, Deusser J, Amato D, et al. Severely impaired hippocampal neurogenesis associates with an early serotonergic deficit in a BAC a-synuclein transgenic rat model of Parkinson's disease. Neurobiol Dis 2016; 85: 206-217.

43. Chung SY, Kishinevsky S, Mazzulli JR, Graziotto J, Mrejeru A, Mosharov EV, et al. Parkin and PINK1 patient iPSC-derived midbrain dopamine neurons exhibit mitochondrial dysfunction and $\alpha$-synuclein accumulation. Stem Cell Reports 2016; 7: 664-677.

44. Albright JE, Stojkovska I, Rahman AA, Brown CJ, Morrison BE. Nestin-positive/SOX2-negative cells mediate adult neurogenesis of nigral dopaminergic neurons in mice. Neurosci Lett 2016; 615: 50-54.

45. Zachrisson O, Zhao M, Andersson A, Dannaeus K, Häggblad J, Isacson R, et al. Restorative effects of platelet derived growth factor-BB in rodent models of Parkinson's disease. J Parkinsons Dis 2011; 1: 49-63.

46. Feigin A, Kieburtz K, Bordwell K, Como P, Steinberg K, Sotack J, et al. Functional decline in Huntington's disease. Mov Disord 1995; 10: 211-214.

47. Ravina B, Romer M, Constantinescu R, Biglan K, Brocht A, Kieburtz K, et al. The relationship between CAG repeat length and clinical progression in Huntington's disease. Mov Disord 2008; 23: 1223-1227.

48. Lazic SE, Grote H, Armstrong RJ, Blakemore C, Hannan AJ, van Dellen A, Barker RA. Decreased hippocampal cell proliferation in R6/1 Huntington's mice. Neuroreport 2004; 15: 811-813.

49. Tattersfield AS, Croon RJ, Liu YW, Kells AP, Faull RL, Connor B. Neurogenesis in the striatum of the quinolinic acid lesion model of Huntington's disease. Neuroscience 2004; 127: 319-332.

50. Zuccato C, Tartari M, Crotti A, Goffredo D, Valenza M, Conti L, et al. Huntingtin interacts with REST/NRSF to modulate the transcription of NRSE-controlled neuronal genes. Nat Genet 2003; 35: 76-83.

51. Gil JM, Rego AC. Mechanisms of neurodegeneration in Huntington's disease. Eur J Neurosci 2008; 27: 28032820.

52. Czeredys M, Maciag F, Methner A, Kuznicki J. Tetrahydrocarbazoles decrease elevated SOCE in medium spiny neurons from transgenic YAC128 mice, a model of Huntington's disease. Biochem Biophys Res Commun 2017; 483: 1194-1205.

53. Czeredys M, Vigont VA, Boeva VA, Mikoshiba K, Kaznacheyeva EV, Kuznicki J. Huntingtin-associated protein 1A regulates store-operated calcium entry in medium spiny neurons from transgenic YAC128 mice, a model of Huntington's disease. Front Cell Neurosci 2018; 12: 381. 